\title{
A Case Report of Giant Lipoma in Right Loin
}

\section{Venkatachalapathy $\mathrm{TS}^{1 *}$, Sreeramulu $\mathrm{PN}^{2}$ and Prathima $\mathrm{S}^{3}$}

${ }^{1}$ Assistant Professor of Surgery, Sri Devaraj URS Medical College \& RL Jalappa Hospital and Research Centre, Tamaka, Kolar, Karnataka, India

${ }^{2}$ Professor of Surgery, Sri Devaraj URS Medical College \& RL Jalappa Hospital and Research Centre, Tamaka, Kolar, Karnataka, India

${ }^{3}$ Associate Professor of Pathology, Sri Devaraj URS Medical College \& RL Jalappa Hospital and Research Centre, Tamaka, Kolar, Karnataka, India

\begin{abstract}
Lipoma is one of the commonest benign mesenchymal tumors in body and found almost in all organs where the fat exists. It is usually small but giant lipomas can be present in thigh, shoulder and trunk. The present study describes a 46 year old male with a huge mass right loin which on histopathology revealed features suggestive of lipoma.
\end{abstract}

Keywords: Lipoma; Subcutaneous; Swelling

\section{Introduction}

Lipoma is one of the most common benign mesenchymal tumors in the body and is composed of mature adipose cells. A lipoma can be found in almost all the organs of the body where fat normally exists, which is why it is also known as aubiquitous tumor or universal tumor. While small superficial lipomas constitute simple surgical conditions, large and deep lipomas represent a real diagnostic and therapeutic challenge. Presentation is usually as a painless subcutaneous swelling. Other presentations depend on the site and size of the lesion and on local pressure effects [1-3].

\section{Case Report}

We report a 46 year old man presented to us with history of swelling in right loin since 10 years. No history of sudden increase or pain in the swelling. He was asymptomatic all these days, because of persistent swelling he came to our OPD. On Examination swelling was occupying right loin and right lumbar region, soft in consistency, no cough impulse, clinically lipoma diagnosis was made. Blood investigations were within normal limits. FNAC revealed lipoma, hence planned for complete surgical excision of lipoma was done. The histopathological examination is lipoma (Figure 1-3).

\section{Discussion}

Giant lipomas, though rare, can present in thigh, shoulder or trunk $[4,5]$. Clinical features of these giant lipomas are mainly because of their size which includes pain because of stretching of adjacent nerves, restriction in movements of the part involved or social embarrassment because of mere size of the swelling.

Although definitive diagnosis of giant lipoma can be made only by histopathological examination, but once suspected, other investigations can provide additional information about the tumour. The characteristics of benign lipoms on ultrasonography, Computed Tomography [6] and Magnetic Resonance Imaging [7] have been well established and even $\mathrm{Tc}^{99}$ DTPA scan have been used to confirm the diagnosis.

Surgery is the treatment of choice of these giant swellings due

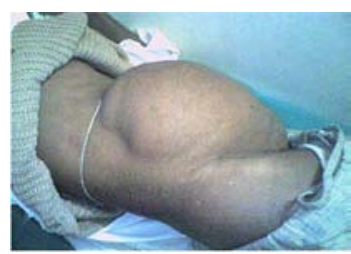

Figure 1: Giant lipoma to their tendency to recur and their potential hazard of malignant transformation, other option for treatment of these giant swelling is liposuction [5]. The dissection of these lipomas is usually easy because of continuous pressure on the surrounding tissue; a well-defined pseudocapsule is formed. Dead space created because of dissection of the giant lipomas is usually drained with the help of a suction drain to avoid collection. As already mentioned, these tumours have tendency to recur and can have malignant transformation, therefore, should be followed meticulously.

Diagnosis is primarily clinical, but malignancy has to be ruled out [8]. In addition to FNAC, MRI has been well established to aid in arriving at a diagnosis and planning for surgery. Features that suggest malignancy include old age, large size, presence of thick septa, presence of nodular and/or globular or nonadipose mass-like areas, and decreased percentage of fat composition. Many of these factors

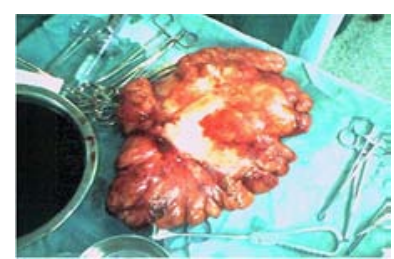

Figure 2: Post excisional specimen.

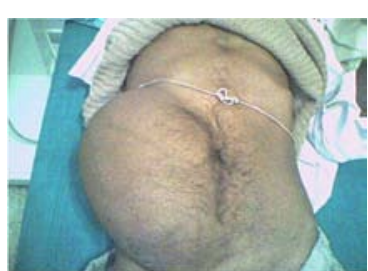

Figure 3: Anterior view.

*Corresponding author: Venkatachalapathy TS, Assistant Professor of Surgery, Sri Devaraj URS Medical College \& RL Jalappa Hospital and Research Centre, Tamaka, Kolar, Karnataka, India, Tel: 8197507094; E-mail: drvenkey@hotmail.com

Received March 28, 2012; Accepted August 25, 2012; Published August 27 2012

Citation: Venkatachalapathy TS, Sreeramulu PN, Prathima S (2012) A Case Report of Giant Lipoma in Right Loin. J Clin Case Rep 2:192. doi:10.4172/2165 7920.1000192

Copyright: (C) 2012 Venkatachalapathy TS, et al. This is an open-access article distributed under the terms of the Creative Commons Attribution License, which permits unrestricted use, distribution, and reproduction in any medium, provided the original author and source are credited. 
Citation: Venkatachalapathy TS, Sreeramulu PN, Prathima S (2012) A Case Report of Giant Lipoma in Right Loin. J Clin Case Rep 2:192. doi:10.4172/2165-7920.1000192

were present in our case. Tocchi et al. [9] suggested that any soft tissue tumor that is greater than $5 \mathrm{~cm}$ should be considered malignant until Proved otherwise. In our case, the size of the tumor was $>5 \mathrm{~cm}$, but histopathology revealed a benign lesion. Surgical excision is the treatment of choicebecause these large tumors may undergo malignant transformation.

The preoperative findings and histopathological features confirmed the diagnoses of benign giant lipoma.These tumors have a tendency for recurrence, and the patients should be kept under a regular follow up.

\section{Conclusion}

The presentation of a long-standing giant lipoma may resemble a malignant lesion. Surgical excision is the treatment of choice to alleviate the symptoms and the apprehension of malignancy and provides tissue diagnosis.

\section{References}

1. Devis C Jr, Gruhn JG (1967) Giant lipoma of the thigh. Arch Surg 95: 151-156.
2. Fornage BD, Tassin GB (1991) Sonographic appearance of superficial soft tissue lipomas. J Clin Ultrasound 19: 215-220.

3. Gluscek S (1987) Giant lipoma of thigh. Wiad Lek 40: 845-848.

4. Hakim E, Kolanden Y, Meller Y, Moses M, Sagi A (1994) Gigantic lipomas Plast Reconstr Surg 94: 369-371.

5. Nichter LS, Gupta BR (1990) Liposuction of giant lipomas. Ann Plast Surg 24 362-365.

6. Wolfe SW, Bansal M, Heely JH, Ghelman B (1989) Computed tomographic evaluation of fatty neoplasms of extremities. A Clinical radiographic and histologic review of cases. Orthopedics 12: 1351-1358.

7. Sundram M, Baran G, Merenda G, McDonald DJ (1990) Myxoid liposarcoma. Magnetic resonance imaging appearance with clinical and histological correction. Skeletal Radiol 19: 359-362.

8. Terzioglu A, Tuncali D, Yuksel A, Bingul F, Aslan G (2004) Giant Lipoma: a series of 12 consecutive cases and a giant liposarcoma of thigh. Dermatol Surg 39: $463-467$.

9. Tocchi A, Maggiolini F, Lepre L, Costa G, Liotta G, et al. (1999) Giant lipoma of thigh: report of a case. G Chir 20: 351-353. 